IOSR Journal of Engineering

Apr. 2012, Vol. 2(4) pp: 591-597

\title{
Estimation of Green House Gas Emission from Indian Coal Based Thermal Power Plant
}

\author{
Satyashree Ghodke ${ }^{1}$, Rohit Kumar ${ }^{2}$, Navneet Singh $^{3}$, Himani khandelwal $^{4}$ \\ Associate Professor ${ }^{1}$, M.Tech. Student $2^{4}$, P.hD Scholar ${ }^{3}$ \\ Technocrats Institute of Technology, Bhopal (M.P. $)^{1,2,4}$, Indian Institute of Technology, (Delhi) ${ }^{3}$
}

\begin{abstract}
Measurements of $\mathrm{CO}_{2}$ (direct GHG) and $\mathrm{CO}, \mathrm{SO}_{2}$, NO (indirect GHGs) were conducted on-line at some of the coal-based thermal power plant in India. The objective of the study having three major objectives: to quantify the measured emissions in terms of emission coefficient per $\mathrm{kg}$ of coal and per $\mathrm{kWh}$ of electricity, to calculate the total possible emission from Indianthermal power plant, and subsequently to compare them with some previous studies. Instrument IMR 2800A Flue Gas Analyzer was used on-line to measure the emission rates of $\mathrm{CO}_{2}, \mathrm{CO}, \mathrm{SO}_{2}$, and $\mathrm{NO}$ at 08 numbers of generating units of different ratings. Certain quality assurance (QA) and quality control (QC) techniques were also adopted to gather the data so as to avoid any ambiguity in subsequent data interpretation. For the betterment of data interpretation, the requisite statistical parameters (standard deviation and arithmetic mean) for the measured emissions have been also calculated. The emission coefficients determined for $\mathrm{CO}_{2}, \mathrm{CO}, \mathrm{SO}_{2}$, and $\mathrm{NO}$ have been compared with their corresponding values as obtained in the studies conducted by other groups. The total emissions of $\mathrm{CO}_{2}, \mathrm{CO}, \mathrm{SO}_{2}$, and $\mathrm{NO}$ calculated on the basis of the emission coefficients find have been found to be 511.944,2.0576,4.473,1.241 Tg respectively.
\end{abstract}

Keywords: Thermal power plant, On-line measurement, Direct and indirect GHG, Emission coefficient

\section{Introduction}

To measure the amount of the direct $\left(\mathrm{CO}_{2}\right)$ and indirect ( $\mathrm{CO}, \mathrm{SO}_{2}$, and $\left.\mathrm{NO}\right) \mathrm{GHGs}$ [5] from the coal-fed Thermal power plant in India, this studyhascarried out.Measurements of these gases were carried out on-line by using IMR 2800A Flue Gas Analyzer at 08 numbers of generating units of varying ratings on different days. The installed electricity generation capacity of the different coal-fed units were 100X3 MW(Obra thermal power station, UPRVNL), 200X2MW(Obra thermal power station,UPRVNL),300X3MW(Rosa thermal power station, reliance power), 154.51X2MW(Dadri thermal power station,NTPC),300X1(Rosa thermal power station, Reliance power) respectively, and most of the units were performing with a plant-load factor of almost equals to unity. The age of the generating units varied from 5 to 40 years.

Studies related to emission measurement and estimations from Thermal power plant conducted by different researchers, scientists, and organizations in past (and Sharma, 2003b, Jorge et al., 2002, Ryerson et al.1998, Gillani et al., 1998, Gurjar et al., 2004, Garg et al.2001, TERI2001a, Varshney and Aggarwal,1992, Chandra and Chandra, 2003, Modeling Anthropogenic Emissions from Energy Activities in India: Generation and Source Characterization) have confirmed the toxic potential of the measured gases particularly with respect to the increasing trend in temperature or in other words global warming. The emission coefficients for different gases have been calculated for different category of generating units by applying statistical methods in this study. The figures have been calculated based on repeatedly measured values following IPCC guidelines [5]. The consistencies of measured values of the generating units were also checked. Certain quality control measures as well as uncertainty reduction methods were adopted during the measurement process, and also find out the emission co-efficient. The variations in emission of the different gases for the different units of the Thermal power plant have been dealt elaborately with specific and pertinent reasoning in the successive paragraphs of Section 3. The emission co-efficient for different gases were obtained for per $\mathrm{kWh}$ of electricity generated as well as per $\mathrm{kg}$ of coal utilized. The emission coefficients have been compared with the values as obtained in the previous studies (Gurjar et al., 2004; Modeling Anthropogenic Emissions from Energy Activities in India: Generation and Source Characterization). Further, the total estimated emission for $\mathrm{CO}_{2}$ has been compared with the study conducted by OSC (Modeling Anthropogenic Emissions from Energy Activities in India: Generation and Source Characterization). since the measurements carried out on-line in plant by following standard experimental guidelines so study gives actual idea regarding the emission carrying out by thermal power plants in India.

\section{Experimental process}

The instrument used for measuring the direct and the indirect GHG emissions was the IMR 2800A Flue Gas Analyzer made by IMR Inc., USA. The instrument was provided by IIT Delhihaving necessary pump and an interconnecting flexible hose with fixed thermocouple sensing wire. As soon as the instrument was switched on, self-calibration started automatically. Fresh air was drawn in by the in-built pump in the instrument from the normal atmosphere through the probe. It also purged out any gas/air present inside the instrument and finally calibration with respect to the oxygen present in the atmosphere. 
IOSR Journal of Engineering

Apr. 2012, Vol. 2(4) pp: 591-597

At the time of measurement, electricity generation records and all other relevant details related to the measurement were noted from the generator control room. Other information on corresponding coal/oil inflow rates were also noted from control room and lab records.

\subsection{Quality assurance (QA)/quality control activity (QC)}

The experimental processes were undertaken following certain quality assurance (QA) and quality control (QC) protocol as formulated in the IPCC Good Practice Guidelines [5]. In the present study, the following quality control measures were adopted:

1) Calibration of the measuring instrument IMR 2800A was done beforemeasurement at each generator unit. Calibration of the instrument IMR 2800A was carried out at a location at the footsteps of the stack since at such locations, the possibility of mixing of the flue gas with the surrounding air was absolutely nil.

2) Measurements were conducted at accessible locations of the flue gas duct. The positions of the locations were maintained to be at sufficient distance from bends and obstructions in the flue ducts, thus possible disturbances arising out of irregular turbulence (due to bends or obstructions) was avoided as per CPCB guidelines [2].

3) The relevant activity data and measured emission figures of this key source category have been properly recorded as per IPCC guidelines [5].

4) Measurements were taken repeatedly at regular time intervals to check consistency in emission values.

5) Standard statistical methods were applied for data interpretation as per IPCC guidelines [5].

\subsection{Statistical methods}

The estimation of the emission co-efficient of different gases has been categorized into four types depending upon the installed capacity, age and location of the plants. The emission coefficients have been obtained by calculating the arithmetic mean of data set as per IPCC guidelines [5] for each category of plants. The standard deviation of the data set (the square root of the variance) has also been calculated for each category of power plant to get better understanding of data.

\section{Results}

The average emission coefficients, their standard deviation values and range for each category of plant are given in Table 2 . The emission coefficient for different gases has been calculated on the basis of actual measurement data. andthese figures were converted to total emission per hour of electricity generation for each generator unit. The standard deviations of such emission coefficients have also been calculated. It should be noted that, though coal quality varied from plants to plant, the combustion technology in all the plants is same which is based on FBC coal burning. However the factors likeoperator effectiveness, fuel composition,FD and ID fans design, ESP design, and ambient temperature have effect on the combustion efficiency resulting variation in emission coefficient of measured gases. Additionally, diesel oil is used in one unit of $100 \mathrm{MW}$ when required to supplement the combustion system for maintaining a stable combustion process during continuous running of the plant. The emission rates of different gases are given in Table 3. The various test results from different units have been categorized in accordance with the installed capacity and age of the generating units and each generating unit has been given a name for identification. Other plants data relevant to the measured values, as available from the respective plant authority, are given in $\underline{\text { Table } 4}$

Table 2. Average emission coefficient of different category of Thermal power plant

\begin{tabular}{|c|c|c|c|c|c|c|c|c|c|}
\hline \multirow[t]{2}{*}{$\begin{array}{l}\text { Plant } \\
(\mathrm{MW})\end{array}$} & \multirow{2}{*}{$\begin{array}{l}\text { Emissi } \\
\text { on } \\
\text { coeffici } \\
\text { ent }\end{array}$} & \multicolumn{4}{|c|}{ Emission per kg coal } & \multicolumn{4}{|c|}{$\begin{array}{l}\text { Emission per unit }(\mathrm{kWh}) \\
\text { electricity }\end{array}$} \\
\hline & & $\begin{array}{l}\mathrm{CO}_{2}(\mathrm{k} \\
\mathrm{g})\end{array}$ & $\begin{array}{l}\mathrm{CO} \\
(\mathrm{g})\end{array}$ & $\begin{array}{l}\mathrm{SO}_{2}( \\
\mathrm{g})\end{array}$ & $\begin{array}{l}\mathrm{NO} \\
(\mathrm{g})\end{array}$ & $\begin{array}{l}\mathrm{CO}_{2}(\mathrm{k} \\
\mathrm{g})\end{array}$ & $\begin{array}{l}\mathrm{CO} \\
(\mathrm{g})\end{array}$ & $\begin{array}{l}\mathrm{SO}_{2}( \\
\mathrm{g})\end{array}$ & $\begin{array}{l}\text { NO } \\
(\mathrm{g})\end{array}$ \\
\hline \multirow[t]{3}{*}{$100 \times 3$} & $\begin{array}{l}\text { Averag } \\
\text { e value }\end{array}$ & 1.453 & 0.831 & 18.91 & 2.863 & 0.814 & 4.631 & 5.823 & 2.230 \\
\hline & S.D. & 0.091 & .396 & 1.964 & 0.927 & 0.020 & 1.224 & 0.432 & 0.559 \\
\hline & Range & $\begin{array}{l}1.426- \\
1.547\end{array}$ & $\begin{array}{l}0.232 \\
- \\
5.216 \\
\underline{b}\end{array}$ & $\begin{array}{l}16.53 \\
- \\
20.72\end{array}$ & $\begin{array}{l}1.620 \\
- \\
4.060\end{array}$ & $\begin{array}{l}0.783- \\
0.839\end{array}$ & $\begin{array}{l}3.080 \\
- \\
8.840 \\
\underline{\mathrm{b}}\end{array}$ & $\begin{array}{l}5.210 \\
- \\
6.312\end{array}$ & $\begin{array}{l}1.643 \\
- \\
2.910\end{array}$ \\
\hline
\end{tabular}




\begin{tabular}{|c|c|c|c|c|c|c|c|c|c|}
\hline \multirow[t]{2}{*}{$\begin{array}{l}\text { Plant } \\
\text { (MW) }\end{array}$} & \multirow{2}{*}{$\begin{array}{l}\text { Emissi } \\
\text { on } \\
\text { coeffici } \\
\text { ent }\end{array}$} & \multicolumn{4}{|c|}{ Emission per kg coal } & \multicolumn{4}{|c|}{$\begin{array}{l}\text { Emission per unit (kWh) } \\
\text { electricity }\end{array}$} \\
\hline & & $\begin{array}{l}\mathrm{CO}_{2}(\mathrm{k} \\
\mathrm{g})\end{array}$ & $\begin{array}{l}\mathrm{CO} \\
(\mathrm{g})\end{array}$ & $\begin{array}{l}\mathrm{SO}_{2}( \\
\mathrm{g})\end{array}$ & $\begin{array}{l}\text { NO } \\
(\mathrm{g})\end{array}$ & $\begin{array}{l}\mathrm{CO}_{2}(\mathrm{k} \\
\mathrm{g})\end{array}$ & $\begin{array}{l}\mathrm{CO} \\
(\mathrm{g})\end{array}$ & $\begin{array}{l}\mathrm{SO}_{2}( \\
\mathrm{g})\end{array}$ & $\begin{array}{l}\text { NO } \\
(\mathrm{g})\end{array}$ \\
\hline \multirow[t]{2}{*}{$300 \mathrm{X} 1$} & $\begin{array}{l}\text { Averag } \\
\text { e value }\end{array}$ & 1.701 & 0.314 & 12.16 & 4.650 & 1.079 & 0.362 & 12.59 & 2.083 \\
\hline & Range $^{\mathrm{a}}$ & $\begin{array}{l}1.632- \\
1.769\end{array}$ & $\begin{array}{l}0.188 \\
- \\
0.353\end{array}$ & $\begin{array}{l}9.712 \\
- \\
15.77\end{array}$ & $\begin{array}{l}4.250 \\
- \\
5.244\end{array}$ & $\begin{array}{l}0.928- \\
1.332\end{array}$ & $\begin{array}{l}0.105 \\
- \\
0.320\end{array}$ & $\begin{array}{l}6.043 \\
- \\
9.812 \\
\end{array}$ & $\begin{array}{l}1.612 \\
- \\
3.263\end{array}$ \\
\hline \multirow[t]{3}{*}{$200 \times 2$} & $\begin{array}{l}\text { Averag } \\
\text { e value }\end{array}$ & 1.652 & 1.207 & 14.23 & 3.512 & 1.183 & 8.961 & 8.560 & 2.823 \\
\hline & S.D. & 0.273 & 0.521 & 3.572 & 0.593 & 0.208 & 2.045 & 1.116 & 0.415 \\
\hline & Range & $\begin{array}{l}1.461- \\
1.813\end{array}$ & $\begin{array}{l}0.532 \\
- \\
1.816\end{array}$ & $\begin{array}{l}11.29 \\
- \\
17.85\end{array}$ & $\begin{array}{l}2.84- \\
4.367\end{array}$ & $\begin{array}{l}0.937- \\
1.496\end{array}$ & $\begin{array}{l}6.698 \\
- \\
10.19 \\
\end{array}$ & $\begin{array}{l}7.473 \\
- \\
9.898 \\
\end{array}$ & $\begin{array}{l}2.167 \\
- \\
3.490\end{array}$ \\
\hline \multirow[t]{3}{*}{$\begin{array}{l}154.51 \\
X 2\end{array}$} & $\begin{array}{l}\text { Averag } \\
\text { e value }\end{array}$ & 1.683 & 0.697 & 15.49 & 3.820 & 0.886 & 1.963 & 7.630 & 2.467 \\
\hline & S.D. & 0.039 & 0.182 & 2.488 & 0.918 & 0.083 & 1.116 & 0.932 & 0.395 \\
\hline & Range & $\begin{array}{l}1.612- \\
1.731\end{array}$ & $\begin{array}{l}0.400 \\
- \\
0.846\end{array}$ & $\begin{array}{l}13.49 \\
- \\
18.19\end{array}$ & $\begin{array}{l}2.68- \\
4.679\end{array}$ & $\begin{array}{l}0.791- \\
0.987\end{array}$ & $\begin{array}{l}0.079 \\
- \\
3.243\end{array}$ & $\begin{array}{l}6.445 \\
- \\
9.113\end{array}$ & $\begin{array}{l}1.912 \\
- \\
2.970\end{array}$ \\
\hline
\end{tabular}

a) This range was measured at only one Thermal power plant. As data on other units are not available, figure for S.D. has not been calculated.

b) Due to oil support in this category of Thermal power plants, the $\mathrm{CO}$ emission is high, which has been reflected in the range of emission for $\mathrm{CO}$.

Table3. Emission rates of greenhouse gases from different thermal power generating units

\begin{tabular}{|c|c|c|c|c|c|c|c|c|}
\hline \multirow{2}{*}{$\begin{array}{l}\text { Generat } \\
\text { or unit }\end{array}$} & \multirow{2}{*}{$\begin{array}{l}\text { Commissio } \\
\text { ned Year }\end{array}$} & \multirow{2}{*}{$\begin{array}{l}\text { Install } \\
\text { ed } \\
\text { capacit } \\
\text { y } \\
(\mathrm{MW})\end{array}$} & \multicolumn{5}{|c|}{ Electricity generation and corresponding emission } & \multirow{2}{*}{$\begin{array}{l}\text { Flue gas } \\
\text { temperat } \\
\text { ure }\left({ }^{\circ} \mathrm{C}\right)\end{array}$} \\
\hline & & & $\begin{array}{l}\text { Generati } \\
\text { on } \\
\text { (MW) }\end{array}$ & $\begin{array}{l}\mathrm{CO}_{2}(\mathrm{~kg} \mathrm{~h} \\
\left.{ }^{-1}\right)\end{array}$ & $\begin{array}{l}\mathrm{CO} \\
\left(\mathrm{kg} \mathrm{h}^{-}\right. \\
\left.{ }^{1}\right)\end{array}$ & $\underset{-1}{\mathrm{SO}_{2}}(\mathrm{~kg} \mathrm{~h}$ & $\begin{array}{l}\mathrm{NO} \\
\left(\mathrm{kg} \mathrm{h}^{-}\right. \\
\left.{ }^{1}\right)\end{array}$ & \\
\hline S1U1 & 1973 & 100 & 100 & 85967.12 & 49.92 & 1168.900 & $\begin{array}{l}183.1 \\
53\end{array}$ & 127 \\
\hline S1U2 & 1975 & 100 & 100 & 92120.36 & 53.76 & 1346.10 & $\begin{array}{l}203.9 \\
1\end{array}$ & 128 \\
\hline S1U3 & 1975 & 100 & 100 & $\begin{array}{l}118468 . \\
48\end{array}$ & $\begin{array}{l}69.86 \\
\underline{a}\end{array}$ & 1763.67 & $\begin{array}{l}221.3 \\
63\end{array}$ & 139 \\
\hline S2U1 & 1980 & 200 & 200 & $\begin{array}{l}204531.2 \\
0\end{array}$ & 180.2 & 1617.28 & $\begin{array}{l}450.8 \\
92\end{array}$ & 137 \\
\hline S2U2 & 1979 & 200 & 200 & 205994.2 & 118.3 & 1925.32 & 421.1 & 127 \\
\hline
\end{tabular}


IOSR Journal of Engineering Apr. 2012, Vol. 2(4) pp: 591-597

\begin{tabular}{|c|c|c|c|c|c|c|c|c|}
\hline \multirow{2}{*}{$\begin{array}{l}\text { Generat } \\
\text { or unit }\end{array}$} & \multirow{2}{*}{$\begin{array}{l}\text { Commissio } \\
\text { ned Year }\end{array}$} & \multirow{2}{*}{$\begin{array}{l}\text { Install } \\
\text { ed } \\
\text { capacit } \\
\mathrm{y} \\
(\mathrm{MW})\end{array}$} & \multicolumn{5}{|c|}{ Electricity generation and corresponding emission } & \multirow{2}{*}{$\begin{array}{l}\text { Flue gas } \\
\text { temperat } \\
\text { ure }\left({ }^{\circ} \mathrm{C}\right)\end{array}$} \\
\hline & & & $\begin{array}{l}\text { Generati } \\
\text { on } \\
(\mathrm{MW})\end{array}$ & $\begin{array}{l}\mathrm{CO}_{2}(\mathrm{~kg} \mathrm{~h} \\
\left.{ }_{-1}\right)\end{array}$ & $\begin{array}{l}\mathrm{CO} \\
\left(\mathrm{kg} \mathrm{h}^{-}\right. \\
1)\end{array}$ & $\begin{array}{l}\mathrm{SO}_{2}(\mathrm{~kg} \mathrm{~h} \\
-1\end{array}$ & $\begin{array}{l}\mathrm{NO} \\
\left(\mathrm{kg} \mathrm{h}^{-}\right. \\
\left.{ }^{1}\right)\end{array}$ & \\
\hline & & & & 0 & 64 & & 32 & \\
\hline S3U1 & 1996 & 154.5 & 154.5 & $\begin{array}{l}137827.9 \\
0\end{array}$ & 61.65 & 1412.86 & $\begin{array}{l}296.9 \\
12\end{array}$ & 133 \\
\hline S3U2 & 1997 & 154.5 & 154.5 & $\begin{array}{l}143963.8 \\
4\end{array}$ & 55.10 & 1182.79 & $\begin{array}{l}342.4 \\
54\end{array}$ & 126 \\
\hline S4U1 & 2009 & 300 & 300 & $\begin{array}{l}261120.7 \\
0\end{array}$ & 48.23 & 1867.77 & $\begin{array}{l}714.2 \\
4\end{array}$ & 144 \\
\hline
\end{tabular}

a) Due to oil support in these Thermal power plants, the $\mathrm{CO}$ emission is high, which has been reflected in the range of emission for $\mathrm{CO}$.

Table 4. Fuel feeding and ID fan delivery rates at the time of GHG measurement at different thermal power generating

\begin{tabular}{|l|l|l|l|l|l|l|l|}
\hline $\begin{array}{l}\text { Generator } \\
\text { unit }\end{array}$ & $\begin{array}{l}\text { Generation } \\
(\mathrm{MW})\end{array}$ & $\begin{array}{l}\text { Coal feed } \\
\text { rate } \\
\left(\text { ton }^{-1}\right)\end{array}$ & $\begin{array}{l}\text { Oil } \\
\text { feed } \\
\text { rate } \\
\left(\mathrm{h}^{-1}\right)\end{array}$ & $\begin{array}{l}\text { ID fan } \\
\text { airflow } \\
\text { rate } \\
\left(\mathrm{m}^{3} \mathrm{~s}^{-1}\right)\end{array}$ & $\begin{array}{l}\text { Ambient } \\
\text { temperature } \\
\left({ }^{\circ} \mathrm{C}\right)\end{array}$ & $\begin{array}{l}\text { Furnace } \\
\text { temperature }\end{array}$ & $\begin{array}{l}\text { Excess } \\
\text { QA } \\
(\%)\end{array}$ \\
\hline S1U1 & 100 & 70.12 & 0 & 117.14 & 33 & 820 & 5.1 \\
\hline S1U2 & 100 & 70.00 & 0 & 124.60 & 34 & 800 & 5.0 \\
\hline S1U3 & 100 & 65.20 & 750 & 129.67 & 36 & 830 & 5.8 \\
\hline S2U1 & 200 & 121.60 & 0 & 196.74 & 35 & 860 & 4.6 \\
\hline S2U2 & 200 & 127.00 & 0 & 206.12 & 36 & 850 & 4.5 \\
\hline S3U1 & 154.5 & 84.35 & 0 & 180.67 & 35 & 920 & 5.6 \\
\hline S3U2 & 154.5 & 83.12 & 0 & 186.52 & 34 & 900 & 5.9 \\
\hline S4U1 & 300 & 153.60 & 0 & 374.78 & 30 & 960 & 6.5 \\
\hline
\end{tabular}

The generating units of $100 \mathrm{MW}$ capacities, naming S1U1, S1U2, S1U3 were installed way back in the year 1973-1975, the oldest amongst the plants where measurement has been carried out so far. Being more than 40 year old units, their operational efficiency have definitely decreased in comparison to newer plants. Perhaps this is the main reason behind the occasional requirement of fuel oil along with coal (see Table 4). It is understood from the plant authority that occasionally oil has to be used for maintaining stability of the combustion

\section{1. $\mathrm{CO}_{2}$ emissions from different plants}

From Table 3 , it is seen that the average $\mathrm{CO}_{2}$ emission inunit $\mathrm{S} 4 \mathrm{U} 1$ is maximum whereas that of unit S1U1isminimum. Since all plants are differentin capacities and hence comparison is difficult that's why data compiled in terms of per $\mathrm{kg}$ of coal as shown in table 2.Emission coefficient per kg of coal calculated and found maximum for $300 \mathrm{MW}$ unit (1.701) and minimum for $100 \mathrm{MW}$ units (1.453). The possible reason behind such a variation may have been the amount of excess air supplied and variation in combustion efficiency of the different units.Since S4U1 is the youngest unit available in all the units and hence giving better efficiency as compared to other units. It is also evident from the coal chemical analysis that unit S4U1 using high carbon coal as compared to other units which implies higher $\mathrm{CO} 2$ generation.it is also confirmed by plant authorities that crushers gives the coal size $6 \mathrm{~mm}$ which gives high retention time and stabilized combustion. 
IOSR Journal of Engineering

Apr. 2012, Vol. 2(4) pp: 591-597

\subsection{CO emissions from different plants}

The average CO emissionwas highest in unit S2U1 while lowestfor S4U1.Again due to the variation in capacity it is difficult to compare $\mathrm{CO}$ emission rate and hence coefficient of $\mathrm{CO}$ emission per $\mathrm{kg}$ of coal has been calculated, from table No.3 and found maximum forcategory S2 while minimum for category S4.The possible reasons behind the variation in emission coefficient may be ofpoor combustion efficiency, low excess air supply and high carbon content in fuel and low retention time of coal particles in furnaces as well as coal particle size feaded to the furnace.

$\mathrm{CO}$ emission range is also high in S1catagory of plant, this is due the fact that one of the plant of this category utilized oil to stabilize the combustion.

\section{3. $\mathrm{SO}_{2}$ emissions from differentplants}

The main reason behind the variation in $\mathrm{SO}_{2}$ emission for the different categories can mostly be attributed due to the varying sulfur content of coal fed into the respective units, firing temperature in the furnace, excess air supplied as well as particle used for fluidization. The average $\mathrm{SO}_{2}$ emissions coefficient in all the four category of plant, $\mathrm{S} 1$ has maximumwhile the categoryS4 emitting the minimum. (see Table 2).

\subsection{NO emissions from differentplants}

The basic reason behind the variation of NO emissions from the different categories may be attributed by the varying amount of fixed nitrogen content in coal, high excess air supplied, high combustion temperature and the variable performance efficiency of the burners in different categories.

From Table 2, it can be seen that the average NO emission from unit S4 was the highest and S1 have lowest. The average NO emission coefficients as measured for the different categories of plant are $4.650 \mathrm{~g} / \mathrm{kg}, 3.820 \mathrm{~g} / \mathrm{kg}, 3.512 \mathrm{~g} / \mathrm{kg}$ and $2.863 \mathrm{~g} / \mathrm{kg}$ respectively.

\section{Discussion}

Thermal power plants are one of the main sources of GHG emission throughout the world. For a very fast developing economy like India, measurement of GHGs' from the Thermal power plantare very much essential in order to find out their values so that necessary policies of reduction of such gases can be formulated. In order to develop strategies of GHG reduction. For that, determinations of methodology-based measured emission coefficients are very much essential. The ranges of the values of the emissions in per $\mathrm{kWh}$ of electricity generated and in per $\mathrm{kg}$ of coal utilized obtained in the present study are provided in Table $\underline{5}$ in comparison to those obtained by OSC[10] and by Gurjar et al. (2004). The emission coefficients calculated in the present study are more or less at par with the values obtained by Gurjar et al. (2004), except for the two indirect GHGs CO and NO (see Table 5). The main variation is likely due to variable combustion technologies in the respective units. At the same time variation of coal quality with regard to carbon content and fixed nitrogen content may have an indirect effect on the variation of $\mathrm{CO}$ and $\mathrm{NO}$ formation. Particularly in case of $\mathrm{CO}$, additional oil support in one of the unit of the plant may be the other possible reason for this mismatch in $\mathrm{CO}$ values. While the co-efficient values obtained for $\mathrm{CO}_{2}$ and $\mathrm{SO}_{2}$ matches closely with that obtained by OSC [10], a more or less four times higher co-efficient values for NO has been reported by OSC. Obviously, there is no doubt that this needs to be further investigated.

Table 5. Comparison of emission coefficients

\begin{tabular}{|c|c|c|c|c|}
\hline \multirow{2}{*}{$\begin{array}{l}\text { Gaseous } \\
\text { type }\end{array}$} & \multicolumn{2}{|c|}{$\begin{array}{l}\text { Range of measured emission } \\
\text { coefficient }\end{array}$} & \multicolumn{2}{|l|}{ Emission coefficients } \\
\hline & Present study & Study by OSC & Gurjar et al. (2004) & $\begin{array}{l}\text { Presentstudy(mean of } \\
\text { all) }\end{array}$ \\
\hline $\mathrm{CO}_{2}$ & $\begin{array}{l}0.783-1.496 \\
\left(\mathrm{~kg} \mathrm{kWh}^{-1}\right)\end{array}$ & $\begin{array}{l}0.8-1.8 \\
\left(\mathrm{~kg} \mathrm{kWh}^{-1}\right)\end{array}$ & $\begin{array}{l}1.739\left(\mathrm{~kg} \mathrm{~kg}^{-1} \text { of }\right. \\
\text { coal })\end{array}$ & $1.622\left(\mathrm{~kg} \mathrm{~kg}^{-1}\right.$ of coal $)$ \\
\hline $\mathrm{SO}_{2}$ & $\begin{array}{l}5.210-9.899 \\
\left(\mathrm{~g} \mathrm{kWh}^{-1}\right)\end{array}$ & 4-18 $\left(\mathrm{g} \mathrm{kWh}^{-1}\right)$ & $\begin{array}{l}14.767\left(\mathrm{~g} \mathrm{~kg}^{-1} \text { of }\right. \\
\text { coal })\end{array}$ & $15.19\left(\mathrm{~g} \mathrm{~kg}^{-1}\right.$ of coal $)$ \\
\hline NO & $\begin{array}{l}1.612-3.490 \\
\left(\mathrm{~g} \mathrm{kWh}^{-1}\right)\end{array}$ & $\begin{array}{l}6-13.1 \\
\left(\mathrm{~g} \mathrm{kWh}^{-1}\right)\end{array}$ & $\begin{array}{l}0.824^{\mathrm{a}}\left(\mathrm{g} \mathrm{kg}^{-1} \text { of }\right. \\
\text { coal })\end{array}$ & $3.71\left(\mathrm{~g} \mathrm{~kg}^{-1}\right.$ of coal $)$ \\
\hline $\mathrm{CO}$ & $0.079-10.19^{\mathrm{b}}$ & Not available & $0.253\left(\mathrm{~g} \mathrm{~kg}^{-1}\right.$ of & $0.762\left(\mathrm{~g} \mathrm{~kg}^{-1}\right.$ of coal $)$ \\
\hline
\end{tabular}


IOSR Journal of Engineering

Apr. 2012, Vol. 2(4) pp: 591-597

\begin{tabular}{|l|l|l|l|l|}
\hline \multirow{2}{*}{$\begin{array}{l}\text { Gaseous } \\
\text { type }\end{array}$} & \multicolumn{2}{|l|}{$\begin{array}{l}\text { Range of measured emission } \\
\text { coefficient }\end{array}$} & \multicolumn{2}{|l|}{ Emission coefficients } \\
\cline { 2 - 5 } & Present study & Study by OSC & Gurjar et al. (2004) & $\begin{array}{l}\text { Presentstudy(mean of } \\
\text { all) }\end{array}$ \\
\hline & & & coal) & \\
\hline
\end{tabular}

a) $\mathrm{NO}_{x}$ as $\mathrm{NO}_{2}$ measured by Gurjar as 1.263 , converted to NO multiplying with a factor of 0.652 .

b) Additional oil support.

It has been considered that a total of 517.116 GKwhelectrical energy was produced from coal-fedThermal power plant for the year 20011-2012 (http://indiabudget.nic.in) in India. This excludes contribution by the captive and other non-conventional power plants. To calculate the total emission of each of these toxic gases, the total range of emission (per kWh of electricity) from all categories of power plants has been selected and their mean emission coefficient has been calculated first with that the total emission for the year 2011-2012 has been estimated. From table 7, it can be observed that the corresponding $\mathrm{CO}_{2}$, $\mathrm{CO}_{\text {, }} \mathrm{SO}_{2}$, and NO values are 465.667, 1.583, 4.058, and $1.129 \mathrm{Tg}$, respectively, for the year 2011-2012

Table 7. Total estimated emission of greenhouse gas from Indian Thermal power plantin the year 2010-2011

\begin{tabular}{|l|l|l|l|l|}
\hline \multirow{2}{*}{} & \multicolumn{3}{l}{ Emission per unit $(\mathrm{kWh})$ of electricity } \\
\cline { 2 - 5 } & $\mathrm{CO}_{2}$ & $\mathrm{CO}$ & $\mathrm{SO}_{2}$ & $\mathrm{NO}$ \\
\hline Range of emission from all power plants & $0.783-$ & $0.079-$ & $5.210-$ & $1.612-$ \\
& $1.496 \mathrm{~kg}$ & $10.19 \mathrm{~g}$ & $9.899 \mathrm{~g}$ & $3.490 \mathrm{~g}$ \\
\hline Average emission coefficient & $0.990 \mathrm{~kg}$ & $3.979 \mathrm{~g}$ & $8.650 \mathrm{~g}$ & $2.400 \mathrm{~g}$ \\
\hline Total estimated emission during year & 511.944 & 2.0576 & 4.473 & 1.241 \\
2011-2012 $\mathrm{a}(\mathrm{Tg})$ & & & & \\
\hline
\end{tabular}

Note: $1 \mathrm{Tg}=1 \mathrm{Mton}=1$ million metric ton.

a) Total generation from coal fired Thermal power plantin India, has been considered to be 517.116 GKwh for the year 2011-2012 (http://indiabudget.nic.in).

Considering $\mathrm{CO}_{2}$ to be the major contributor to the greenhouse effect, the measured emission of $465.667 \mathrm{Mton}$ for the year 2011-2012, has been compared with the calculated value obtained by OSC for the year 1997-1998 which was found to be 395 Mton. The thermal power generation for 1997-1998 was 336,000 GWh[10] while that for the period 2011-2012is517.116 GKwh(http://indiabudget.nic.in). This reflects that there is not much variation exists between the present study and that reported by OSC (Modeling Anthropogenic Emissions from Energy Activities in India: Generation and Source Characterization) at least for carbon dioxide taking into consideration the increased generation of electricity from 1997-1998 to 2011-2012.

\section{Conclusion}

From the foregoing discussions, it can be generalized that the emission rates of the direct and indirect GHGs obtained from the Indian Thermal power plant varies on various accounts; such as
a) Quality of coal mixture.
b) quantity of oil used
c) Quantity of coal and oil required for per unit generation.
d) age of the plant and its maintenance standard; and
e) Amount of excess air fed into the furnace.
f) Technology of combustion. 
IOSR Journal of Engineering

Apr. 2012, Vol. 2(4) pp: 591-597

The quality of coal (from different sources) is variable over a wide range. For a particular power plant, a single quality standard cannot be adhered to, as the mixing ratio of different quality of coal cannot be specified. At the same time, the mixture remains non-homogenous. Moreover, the quantity of coal and oil requirement varies in accordance with their calorific value to meet a specific electrical demand. Again efficiency of the plant and equipment, particularly the combustion and heat absorption is varying in nature. The efficiency is again dependent on the age of the plant and the standard of regular preventive maintenance. Further arrangements cannot be made for homogenous mixing of air and fuel at every location of the furnace, resulting in nonhomogenous temperature zones in the furnace resulting in the variation in both (direct as well as indirect) GHG production. At the same time, the amount of excess air plays an important role in the combustion and generation of $\mathrm{NO}$ and $\mathrm{SO}_{2}$. As the variability of all the above factors in all the generatingplants in India remains random in nature, the emission coefficients cannot be quantified easily. So, establishing a relationship between above factors and the emission coefficient is not straightforward. Only, more accuracy in estimating total GHG emission can be achieved if measurement is conducted on almost all the power plants in India. To find out qualitatively better emission coefficients, on-line measurement should be conducted at all suchThermal power plant in India. The present study sets the direction to such an endeavor.

\section{References}

1. A. Chandra, H. Chandra,(2009)Environmental management for cleanpower generation in thermal power plant: an Indian perspective, Indian Journal of Air Pollution Control

2. Environment Acts Rules Notifications, (1999),Environment Acts Rules and Notifications, Department of Environment, Government of india.

3. A. Garg, S. Bhattacharya, R.P. Shukla, K.V. Dadhwal,(2001),Regional and sectorial assessment of greenhouse gas emissions in India.

4. N.V. Gillani, J.F. Meagher, R.J. Valente, R.E. Imhoff, R.L. Tanner, M. Luria,(1998),Relative production of ozone and nitrates in urban and ruralpower plant plumes. Journal of Geophysical Research.

5. Good Practice Guidance and Uncertainty Management in National Greenhouse Gas Inventories Good Practice Guidance and Uncertainty Management in National Greenhouse Gas Inventories. http://www.ipcc-ggip.iges.or.jp/public/gp/gpgaum.

6. R.B. Gurjar, A.J. Van Aardenne, J. Lelieveld, M. Mohan,(2004),Emission estimates and trends (1990-2000) for mega city Delhi and implication.

7. http://indiabudget.nic.in,http://indiabudget.nic.in

8. Jorge, F. Manzini, M. Martinez, (2007) Renewable energies in electricity generation for reduction of greenhouse gases in Mexico 2025.

9. Mitta M.L., Sharma, C., 2003. Anthropogenic emissions from energy activities in India: generation and source characterization. Part I: emissions from thermal power generation in India. URL: http://www.osc.edu/research/pcrm/emissions/India.pdf.

10. Modeling Anthropogenic Emissions from energy activities in India, Modeling anthropogenic emissions from energy activities in India: generation and source characterization.www.osc.edu/research/pcrm/emissions/contents.

11. T.B. Ryerson, M.P. Buhr, G.J. Frost, P.D. Goldan, J.S. Holloway, G. Hubler, B.T. Jobson, W.C. Kuster, S.A. McKeen, D.D. Parrish, J.M. Roberts, D.T. Sueper, M. Trainer, J. Williams, C.F.Fehsenfeld,(1998)Emissions lifetimes and ozone formation inpower plant plumes, Journal of Geophysical

12. TERI (The Energy and Resources Institute), 2001, State of environment report for Delhi 2001. Report No. 2000EE65, Supported by the Department of Environment, Government of National Capital Territory, Delhi.

13. K.C. Varshney, M. Aggarwal, (1992), Ozone pollution in the urban environment of Delhi. 